\title{
Editorial \\ Miniaturized Pyrotechnic Systems Meet the Performance Needs While Limiting the Environmental Impact
}

\author{
Carole Rossi ${ }^{1, *(1)}$ and Ruiqi Shen ${ }^{2}$ (I) \\ 1 LAAS-CNRS, University of Toulouse, 7 Avenue du Colonel Roche, 31400 Toulouse, France \\ 2 School of Chemical Engineering, Nanjing University of Science and Technology, Nanjing 210096, China; \\ rqshen@njust.edu.cn \\ * Correspondence: rossi@laas.fr
}

Citation: Rossi, C.; Shen, R. Miniaturized Pyrotechnic Systems Meet the Performance Needs While Limiting the Environmental Impact. Micromachines 2022, 13, 376. https://doi.org/10.3390/ mi13030376

Received: 25 February 2022 Accepted: 25 February 2022 Published: 26 February 2022

Publisher's Note: MDPI stays neutral with regard to jurisdictional claims in published maps and institutional affiliations.

Copyright: (C) 2022 by the authors. Licensee MDPI, Basel, Switzerland. This article is an open access article distributed under the terms and conditions of the Creative Commons Attribution (CC BY) license (https:// creativecommons.org/licenses/by/ $4.0 /)$.
Pyrotechnic systems, also termed pyrotechnics, refer to a broad family of sophisticated single-use devices that are able to produce heat, light, smoke, sound, motion, and/or a combination of these thanks to the reaction of an energetic material (primary and secondary explosives, powders/propellants, and other pyrotechnic substances). Most pyrotechnics utilize a simple hot wire or bridgewire to initiate the energetic material reaction and are used to perform a large variety of functions in large equipment, such as release, cutting, pressurization, valving, ignition, switching, and other mechanical works. Their applications are expanding in defense, civil engineering, demolition, fireworks, automotive, and space industries and are enjoying good safety records.

Two decades ago, the concept of micro-pyrotechnics emerged with the idea of reducing the manufacturing cost by applying collective microelectronic processing $\mathrm{w}$ to lower the ignition energy costs while improving both vulnerability and safety requirements by replacing the simple hot wire with a sophisticated arm and fire electronic unit.

At this stage, it was only very early thinking about how to manufacture new performing pyrotechnically actuated microsystems. The concept was considered only "technically feasible", and researchers hoped to provide a cogent view that a new era in pyrotechnics was upon us, wherein the micro-nanotechnologies and simulation would allow entirely new capabilities to be developed with exciting advancements in the fields of propulsion, actuation, and thermics. Consequently, an active research effort was born internationally on both the design and elaboration of new nano-energetical materials (nano-energetics $[1,2]$ ) and the demonstration of new functionalities such as micro-actuators [3-5], micro-thrusters [6-11], tunable initiation of secondary explosives [12-15], joining, brazing, and sealing [16].

Two decades later, in 2022, advancements in energetic materials and micro-pyrotechnics are considerable, and the opportunity for new capabilities for industries built on micropyrotechnics is upon us.

This Special Issue illustrates some of the works of the groups engaged in this research field. The first paper by Pouchairet and co-workers [17] presents the development of a miniaturized smart infrared (IR) electronically controllable flare combining a microinitiation stage that integrates low-energy addressable pyroMEMS (pyrotechnical microelectromechanical systems) with a structured IR pyrotechnical loaf. Miniaturization is a key point of this work, but the choice of environmentally benign materials and technologies is also significant. Another series of papers presents innovative research on energetic composites that can be integrated into miniaturized devices for initiation. Liu and co-workers [18] develop a new composite energetic film $\left(\mathrm{Cu}\left(\mathrm{N}_{3}\right)_{2}\right)$ on a MEMS chip, which presents high reactivity with better safety. $\mathrm{Yu}$ and co-workers [19] present a new generic synthesis route for $\mathrm{CoFe}_{2} \mathrm{O}_{4} / \mathrm{Al}$ nanothermite films by integrating $\mathrm{Al}$ nanoparticles with $\mathrm{CoFe}_{2} \mathrm{O}_{4}$ nanowires. Interestingly, this method is totally compatible with MEMS technologies and can be applied to diverse thermite systems, such as $\mathrm{MnCo}_{2} \mathrm{O}_{4}$ and $\mathrm{NiCo}_{2} \mathrm{O}_{4}$. He and co-workers [20] developed an explosive ink that can be printed layer by layer, each single layer being $\sim 10 \mu \mathrm{m}$. 
The critical detonation size of the sample can reach $1 \mathrm{~mm} \times 0.01 \mathrm{~mm}$ or less, and the detonation velocity can achieve $8686 \mathrm{~m} \cdot \mathrm{s}^{-1}$, which exhibits excellent micro-scale detonation ability. Finally, the two last papers consider miniaturized initiation devices. Wang and coworkers [21] present exploding foil microinitiators completely fabricated by MEMS-based engineering, which can be triggered by Metal-Oxide Semiconductor-Controlled Thyristor. Additionally, Lei and co-workers [22] integrate $\mathrm{Cu} / \mathrm{Ni}$ Multilayer Exploding Foil on MEMS chips by Magnetron Sputtering and Electroplating.

It is only a snapshot of the current state of this research field, but these papers may encourage readers to investigate further. One important requirement for future miniaturized pyrotechnical systems is meeting the performance needs while maintaining a low cost and minimizing the environmental impact. Although it seems difficult to minimize the impact of a device that involves the combustion of fuel with the subsequent emission of gaseous and unburnt products, the choice of ingredients, such as environmentally friendly thermite, and the design of the system can reduce that impact significantly.

Conflicts of Interest: The authors declare no conflict of interest.

\section{References}

1. Zachariah, M.R. NanoEnergetics: Hype, Reality and Future. Propell. Explos Pyrot. 2013, 38, 7.

2. Glavier, L.; Taton, G.; Ducere, J.M.; Baijot, V.; Pinon, S.; Calais, T.; Esteve, A.; Djafari-Rouhani, M.D.; Rossi, C. Nanoenergetics as pressure generator for nontoxic impact primers: Comparison of $\mathrm{Al} / \mathrm{Bi} 2 \mathrm{O} 3, \mathrm{Al} / \mathrm{CuO}, \mathrm{Al} / \mathrm{MoO} 3$ nanothermites and $\mathrm{Al} / \mathrm{PTFE}$. Combust Flame 2015, 162, 1813-1820. [CrossRef]

3. Rodriguez, G.A.A.; Suhard, S.; Rossi, C.; Esteve, D.; Fau, P.; Sabo-Etienne, S.; Mingotaud, A.F.; Mauzac, M.; Chaudret, B. A microactuator based on the decomposition of an energetic material for disposable lab-on-chip applications: Fabrication and test. J. Micromech. Microeng. 2009, 19, 015006. [CrossRef]

4. De Koninck, D.A.; Lopez, F.M.; Briand, D.; de Rooij, N.F. Foil-Level Fabrication of Inkjet-Printed Pyromems Balloon Actuators. In Proceedings of the 2012 IEEE 25th International Conference on Micro Electro Mechanical Systems (Mems), Paris, France, 29 January-2 February 2012.

5. Nicollet, A.; Salvagnac, L.; Baijot, V.; Estève, A.; Rossi, C. Fast circuit breaker based on integration of $\mathrm{Al} / \mathrm{CuO}$ nanothermites. Sens. Actuators A Phys. 2018, 273, 249-255. [CrossRef]

6. Larangot, B.; Rossi, C.; Camps, T.; Berthold, A.; Pham, P.; Briand, D.; Puig-Vidal, M.; Miribel, P.; Esteve, D.; Rooij, N.D.; et al. Solid Propellant Micro Rockets-Towards a New Type of Power MEMS. In NanoTech 2002_-At the Edge of Revolution"; AIAA: Houston, TX, USA, 2002.

7. Larangot, B.; Conedera, V.; Dureuil, P.; Do Conto, T.; Rossi, C. Solid propellant microthruster: An alternative propulsion device for nanosatellite. In Proceedings of the 2002 Aerospace Energetic Equipment Conference, Avignon, France, 3-5 July 2019.

8. Zhang, K.L.; Chou, S.K.; Ang, S.S.; Tang, X.S. A MEMS-based solid propellant microthruster with Au/Ti igniter. Sens. Actuat. A-Phys. 2005, 122, 113-123. [CrossRef]

9. Staley, C.S.; Raymond, K.E.; Thiruvengadathan, R.; Apperson, S.J.; Gangopadhyay, K.; Swaszek, S.M.; Taylor, R.J.; Gangopadhyay, S. Fast-Impulse Nanothermite Solid-Propellant Miniaturized Thrusters (vol 29, pg 1400, 2013). J. Propul. Power 2015, 31, 483. [CrossRef]

10. Tanaka, S.; Hosokawa, R.; Tokudome, S.; Hori, K.; Saito, H.; Watanabe, M.; Esashi, M. MEMS-based solid propellant rocket array thruster with electrical feedthroughs. T Jpn Soc. Aeronaut. S 2003, 46, 47-51. [CrossRef]

11. Ru, C.; Wang, F.; Xu, J.; Dai, J.; Shen, Y.; Ye, Y.; Zhu, P.; Shen, R.Q. Superior performance of a MEMS-based solid propellant microthruster (SPM) array with nanothermites. Microsyst. Technol. 2016, 23, 3161-3174. [CrossRef]

12. Glavier, L.; Nicollet, A.; Jouot, F.; Martin, B.; Barberon, J.; Renaud, L.; Rossi, C. Nanothermite/RDX-Based Miniature Device for Impact Ignition of High Explosives. Propell. Explos. Pyrot. 2017, 42, 307-316. [CrossRef]

13. Staley, C.S.; Morris, C.J.; Thiruvengadathan, R.; Apperson, S.J.; Gangopadhyay, K.; Gangopadhyay, S. Silicon-based bridge wire micro-chip initiators for bismuth oxide-aluminum nanothermite. J. Micromech. Microeng. 2011, 21, 115015. [CrossRef]

14. Fu, S.; Shen, R.Q.; Zhu, P.; Ye, Y.H. Metal-interlayer-metal structured initiator containing Al/CuO reactive multilayer films that exhibits improved ignition properties. Sens. Actuat. A-Phys. 2019, 292, 198-204. [CrossRef]

15. Dai, J.; Wang, C.G.; Wang, Y.T.; Xu, W.; Xu, J.B.; Shen, Y.; Zhang, W.; Ye, Y.H.; Shen, R.Q. From nanoparticles to on-chip 3D nanothermite: Electrospray deposition of reactive $\mathrm{Al} / \mathrm{CuO} @ \mathrm{NC}$ onto semiconductor bridge and its application for rapid ignition. Nanotechnology 2020, 31, 195712. [CrossRef] [PubMed]

16. Dombroski, D.M.B.; Wang, A.Q.; Wen, J.Z.; Alfano, M. Joining and welding with a nanothermite and exothermic bonding using reactive multi-nanolayers-A review. J. Manuf. Process. 2022, 75, 280-300. [CrossRef]

17. Pouchairet, J.L.; Rossi, C. PyroMEMS as Future Technological Building Blocks for Advanced Microenergetic Systems. Micromachines 2021, 12, 118. [CrossRef] [PubMed] 
18. Liu, X.; Hu, Y.; Wei, H.; Chen, B.; Ye, Y.; Shen, R. Energetic Films Realized by Encapsulating Copper Azide in Silicon-Based Carbon Nanotube Arrays with Higher Electrostatic Safety. Micromachines 2020, 11, 575. [CrossRef] [PubMed]

19. Yu, C.; Ren, W.; Wu, G.; Zhang, W.; Hu, B.; Ni, D.; Zheng, Z.; Ma, K.; Ye, J.; Zhu, C. A Facile Preparation and Energetic Characteristics of the Core/Shell CoFe2O4/Al Nanowires Thermite Film. Micromachines 2020, 11, 516. [CrossRef] [PubMed]

20. He, Y.; Guo, X.; Long, Y.; Huang, G.; Ren, X.; Xu, C.; An, C. Inkjet Printing of GAP/NC/DNTF Based Microscale Booster with High Strength for PyroMEMS. Micromachines 2020, 11, 415. [CrossRef] [PubMed]

21. Wang, K.; Zhu, P.; Xu, C.; Zhang, Q.; Yang, Z.; Shen, R. Firing Performance of Microchip Exploding Foil Initiator Triggered by Metal-Oxide-Semiconductor Controlled Thyristor. Micromachines 2020, 11, 550. [CrossRef] [PubMed]

22. Lei, F.; Ye, Q.; Yang, S.; Fu, Q. Study on Electrical Explosion Properties of Cu/Ni Multilayer Exploding Foil Prepared by Magnetron Sputtering and Electroplating. Micromachines 2020, 11, 528. [CrossRef] [PubMed] 